\title{
Antibacterial Activity of EthylAcetate Extract of Platycladus orientalis against Staphylococcus saprophyticus
}

\author{
Emad Mohamed Abdallah ${ }^{1 *}$ and Eman Ramadan Elsharkawy ${ }^{2,3}$ \\ ${ }^{1}$ Department of Laboratory Sciences, College of Sciences and Arts at Al-Rass, Qassim University, Al-Rass, Saudi \\ Arabia. ${ }^{2}$ Department of Eco- physiology, Desert Research Center, 15753, Cairo, Egypt. ${ }^{3}$ Chemistry Department, \\ Faculty of Science, Northern Borders University, Saudi Arabia.
}

\begin{abstract}
Fruits of Platycladus orientalis growing wild in Arar region, Saudi Arabia was investigated for its antibacterial activity against Staphylococcus saprophyticus. A bacterium associate with serious urinary tract infections (UTI) and cystitis in young human females. GC-MS analysis discloses the presence of some bioactive compounds, such as cupressene, podocarpa-8,11,13-triene, kauran-16-ol, kerruginol, glycoside compounds, cymarin and Periplocymarin which could be attributed to the antibacterial efficacy of that plant product. The extract showed remarkable antibacterial activity against Staphylococcus saprophyticus, the disc diffusion test recorded $16.0 \pm 1.0 \mathrm{~mm}$ zone of inhibition, with relative percentage inhibition (RPI) of Platycladus orientalis extract was $66.6 \%$ compared with the chloramphenicol. The $M I C$ and $M B C$ values were $12.5 \mathrm{mg} / \mathrm{ml}$ and $50 \mathrm{mg} / \mathrm{ml}$, respectively. The $\mathrm{MBC} / \mathrm{MIC}$ ratio was 4, indicating that the extract has a good bacteriostatic effect. Therefore, the fruits of Platycladus orientalis could be used in the formulation of antibacterial drugs against Staphylococcus saprophyticus associated with UTI infections.
\end{abstract}

Keywords: Platycladus orientalis, GC-MS, antibacterial, Staphylococcus saprophyticus.

*Correspondence: emad100sdl@yahoo.com

(Received: 28 January 2019; accepted: 13 April 2019)

Citation: Emad Mohamed Abdallah and Eman Ramadan Elsharkawy, Antibacterial Activity of Ethyl Acetate Extract of Platycladus orientalis against Staphylococcus saprophyticus, J Pure Appl Microbiol., 2019; 13(2): 1063-1068. doi: 10.22207/JPAM.13.2.44

(c) The Author(s) 2019. Open Access. This article is distributed under the terms of the Creative Commons Attribution 4.0 International License which permits unrestricted use, sharing, distribution, and reproduction in any medium, provided you give appropriate credit to the original author(s) and the source, provide a link to the Creative Commons license, and indicate if changes were made. 


\section{INTRODUCTION}

Medicinal plants have been used since times immemorial and the accumulated knowledge in herbal formulations were passed down throughout ancient civilizations until reach recent history where drug discoveries led to the isolation of numerous medications from medicinal plants such as morphine, quinine, digitoxin, cocaine, codeine and many more ${ }^{1}$. With the turn of the twentieth century, the discovery of antibiotics has given humans victory over pathogenic microbes. The discovered antibiotics were initially natural product secretions, isolated form fungi, bacteria and environmental microorganisms. Several decades later, the molecular genetic system of microbes developed resistance against these antibiotics, which led to the need to find urgent alternatives, under the absence of any newly discovered antibiotics in the last 30 years ${ }^{2}$. The growing problem of antibiotics resistance has led to raising the interest of medicinal plant investigations particularly those with ethnopharmacological heritage to uncover new antimicrobial agents ${ }^{3}$. Platycladus orientalis Linn. (Synonymous: Thuja orientalis) is belong to family Cupressaceae, it is a coniferous shrub with evergreen and scale-like leaves; It is used in traditional medicine in the treatment of bronchitis, cystitis, enuresis, psoriasis, amenorrhea, uterine carcinomas and rheumatism ${ }^{4}$. The essential oils obtained from Platycladus orientalis contains $\beta$-thujone and $\beta$-thujone which showed toxic effects on ruminant animals ${ }^{5}$. However, the ethanol extract of Platycladus orientalis is nontoxic at low concentration $(\leq 0.6 \mathrm{mg} / \mathrm{ml})$ and it suppressed the growth of human lung cancer cell line ${ }^{6}$. Staphylococcus saprophyticus is a Gram-positive coccus, a leading cause of urinary tract infections (UTI) and cystitis in young human females with virulent strains resistant to many UTI antibiotics such as fosfomycin trometamol and cefixime ${ }^{7}$. The present investigation is aimed to study the efficacy of ethyl acetate extract of Platycladus orientalis against referenced strain of Staphylococcus saprophyticus.

\section{MATERIALS AND METHODS Plant Material}

The fruits of Platycladus orientalis were collected from Arar region, Northern area,
Saudi Arabia in March 2018. An authenticated sample was deposited in Faculty of science girl section. Fruits were cut in to small pieces, dried in incubator at $40^{\circ} \mathrm{C}$ for up to a week and ground to a fine powder.

\section{Plant extraction}

The air-dried powdered fruit (100 g) of Platycladus orientalis were subjected to successive extraction by percolation in ethyl acetate for a week. Then, the percolate was filtered and the solvent was evaporated by rotary evaporator under reduced pressure, until dryness. The extract $(18.00 \mathrm{~g})$ was dissolved in a suitable amount of distilled $\mathrm{H}_{2} \mathrm{O}-\mathrm{MeOH}(95: 5 \mathrm{v} / \mathrm{v})$ then the extract was kept for GC-MS analysis.

\section{GC-MS analysis}

The compounds were analyzed using a Thermo GC-Trace ultra system (Thermo Co. USA), they were separated on $30 \mathrm{~m} \times 0.25 \mathrm{~mm} \times 0.25 \mu \mathrm{m}$ Elite-5MS column (Thermo Scientific GC Column). The column temperature was increased from $40^{\circ} \mathrm{C}$ to $220^{\circ} \mathrm{C}$ at a rate of $4^{\circ} \mathrm{C} / \mathrm{min}$; injector temperature is 250 oC; injection volume is $1 \mu$ l; helium carrier gas flow rate is $20 \mathrm{ml} / \mathrm{min}$; transfer temperature is $280^{\circ} \mathrm{C}$. MS parameters were as follows: $\mathrm{EI}$ mode, with ionization voltage $70 \mathrm{ev}$, ion source temperature, $180 \mathrm{oC}$; scan range, $50-600 \mathrm{Da}$. The peaks were tentatively identified based on library search using NIST and Wiley Registry 8 Edition.

\section{Antibiotic susceptibility testing}

The antibiotics susceptibility profile of Staphylococcus saprophyticus ATCC 43867 was performed using Kirby-Bauer disk diffusion method following the guideline of Clinical and Laboratory Standards Institute $(\mathrm{CLSI})^{8}$. Briefly, an overnight culture from Staphylococcus saprophyticus isolate was adjusted to be equivalent to $0.5 \mathrm{McF}$ arland. $100 \mu \mathrm{l}$ of the adjusted suspension was streaked over sterile Mueller-Hinton agar. Then, standard antibiotic rings (Mastring- $\mathrm{S}^{\mathrm{TM}} \mathrm{MOH} 50 / 2$ and $\mathrm{MOH} 50 / 3$ ) were aseptically loaded in to streaked plates and incubated for up to $18 \mathrm{~h}$ at $37 \mathrm{o} \mathrm{C}$. The zone of inhibition around the antibiotic discs were measured and recorded as resistant or sensitive according the manufacturer's instructions that are based on the CLSI guidelines.

\section{Antibacterial activity assay}

The antibacterial activity of Platycladus orientalis ethyl acetate extract against Staphylococcus saprophyticus was initially 
determined using disc diffusion method ${ }^{9}$, with minor modifications. The extract was reconstituted in dimethyl sulfoxide (DMSO) to get concentration $300 \mathrm{mg} / \mathrm{ml}$., DMSO has no effect on the bacterial growth. The bacterial suspension was adjusted to 0.5 McFarland standard $\left(1 \times 10^{8}\right.$ $\mathrm{CFU} / \mathrm{ml}$ ). $100 \mu \mathrm{l}$ of the adjusted suspension was spread over a sterile Mueller-Hinton Petri-dishes and left for a while. $6 \mathrm{~mm}$ paper discs (made from Whatman No. 1) were impregnated with about $20 \mu \mathrm{L}$ of the extracts and placed on the inoculated Mueller Hinton agar Petri-dish, a disc saturated with about $20 \mu \mathrm{L}$ Chloramphenicol $(5 \mathrm{mg} / \mathrm{ml})$ was also placed on the plate to serve as control. The Petri-dish was incubated at $37^{\circ} \mathrm{C}$ for overnight and the diameters of the inhibition zones were measured.

\section{Minimum inhibitory concentration (MIC)}

The MIC of the extract was evaluated by tube dilution method ${ }^{10}$. The various two-folds dilutions of the extract $(6.25,12.5,25,50,100$ and $200 \mathrm{mg} / \mathrm{ml}$ ) were made in tubes containing nutrient broth. Equal volume of the extract and nutrient broth were mixed in each test tube. $0.1 \mathrm{ml}$ of adjusted inoculum of Staphylococcus saprophyticus ( $1^{\prime} 10^{8} \mathrm{CFU} / \mathrm{ml}$ ) was added to each tube. All tubes were incubated for 18 hours at $37^{\circ} \mathrm{C}$. Two control tubes were also maintained,one was positive control contains antibiotic instead of extract and the other one is a negative control contains bacterial inoculum, physiological saline

Table 1. GC-MS analysis of ethyl acetate fraction of fruit of Platycladus orientalis

\begin{tabular}{|c|c|c|c|}
\hline No. & Compounds & $\begin{array}{l}\text { Chemical } \\
\text { structure }\end{array}$ & $\begin{array}{l}\text { Percentage } \\
\text { (\%) }\end{array}$ \\
\hline 1 & Cymarin & $\mathrm{C}_{30} \mathrm{H}_{44} \mathrm{O}_{9}$ & 2.3 \\
\hline 2 & Periplocymarin & $\mathrm{C}_{30} \mathrm{H}_{46}^{44} \mathrm{O}_{8}$ & 2.5 \\
\hline 3 & Cupressene & $\mathrm{C}_{20}^{30} \mathrm{H}_{32}^{46}{ }^{8}$ & 0.23 \\
\hline 4 & $\begin{array}{l}\text { Podocarpa-8,11, } \\
\text { 13-triene }\end{array}$ & $\mathrm{C}_{17}^{20} \mathrm{H}_{24}^{32}$ & 0.62 \\
\hline 5 & $\begin{array}{l}\text { Keto-Dihydro- } \\
\text { gendunin }\end{array}$ & $\mathrm{C}_{26} \mathrm{H}_{32} \mathrm{O}_{6}$ & 0.23 \\
\hline 6 & Methyl abietate & $\mathrm{C}_{21} \mathrm{H}_{32} \mathrm{O}_{2}$ & 0.45 \\
\hline 7 & Kauran-16-ol & $\mathrm{C}_{20} \mathrm{H}_{34} \mathrm{O}^{2}$ & 1.4 \\
\hline 8 & $\begin{array}{l}\text { Isosteviol } \\
\text { methyl ester }\end{array}$ & $\mathrm{C}_{21} \mathrm{H}_{32} \mathrm{O}_{3}$ & 1.2 \\
\hline 9 & Ferruginol & $\mathrm{C}_{20} \mathrm{H}_{30} \mathrm{O}$ & 5.5 \\
\hline 10 & Thunbergol & $\mathrm{C}_{20} \mathrm{H}_{34} \mathrm{O}$ & 3.2 \\
\hline
\end{tabular}

and broth medium. MIC was considered as the lowest concentration of the extract showing no visible growth (no turbidity) when compared with the control tubes.

Minimum bactericidal concentration (MBC)

$\mathrm{MBC}$ was determined by sub-culturing the MIC test dilutions ${ }^{11}$. Briefly, $50 \mu \mathrm{l}$ of the incubated test tubes (from the MIC assay) was pipetted and transferred to sterile nutrient agar plates, incubated overnight at $37^{\circ} \mathrm{C}$ and inspected for visible growth on the agar. The lowest concentration of MIC which exhibited no visible bacterial growth on agar medium was taken as MBC.

\section{Relative percentage inhibition (RPI)}

The relative percentage inhibition $(\mathrm{RPI})^{12}$ of $5 \mathrm{mg} / \mathrm{ml}$ chloramphenicol ( $10 \mathrm{mg} /$ disc) $300 \mathrm{mg} /$ $\mathrm{ml}$ Platycladus orientalis extract $(20 \mu \mathrm{L} /$ disc) with respect to Staphylococcus saprophyticus was calculated using the following formula:

Table 2. Antibiotic profile of Staphylococcus saprophyticus*

\begin{tabular}{lcc}
\hline Sensitive & Resistant & Antibiotic \\
\hline+ & - & $\mathrm{C}$ \\
- & + & $\mathrm{CAZ}$ \\
+ & - & $\mathrm{IMI}$ \\
+ & - & $\mathrm{CIP}$ \\
+ & - & $\mathrm{PRL}$ \\
+ & - & $\mathrm{T}$ \\
+ & - & $\mathrm{AK}$ \\
- & + & $\mathrm{ATM}$ \\
- & + & $\mathrm{AUG}$ \\
- & + & $\mathrm{CTX}$ \\
- & + & $\mathrm{OFX}$ \\
- & + & $\mathrm{KF}$ \\
+ & - & $\mathrm{TS}$ \\
+ & - & $\mathrm{GM}$ \\
+ & - & $\mathrm{TN}$ \\
- & + & $\mathrm{AP}$ \\
\hline &
\end{tabular}




$$
\mathrm{RPI} \%=\frac{100 X(X-Y)}{Z-Y}
$$

Where: $(X)$ is the total area of inhibition of the herbal extract, $(Y)$ is the total area of inhibition of the solvent and ( $Z$ ) is total area of inhibition of the antibiotic. The total area of the inhibition zone was calculated based on the following equation:

$$
\text { Area }=\pi X r^{2}
$$

where: $(r)$ is the radius of the zone of inhibition, $\pi=3.14$

\section{RESULTS AND DISCUSSION}

Medicinal herbs were the primary source of drugs since ancient times and till now. In the current investigation, the GC-MS analysis of ethyl acetate extract of Platycladus orientalis fruits revealed the presence of some important bioactive compounds, such as Ferruginol (5.5\%), Thunbergol (3.2\%), Periplocymarin (2.5\%), Cymarin (2,3\%),

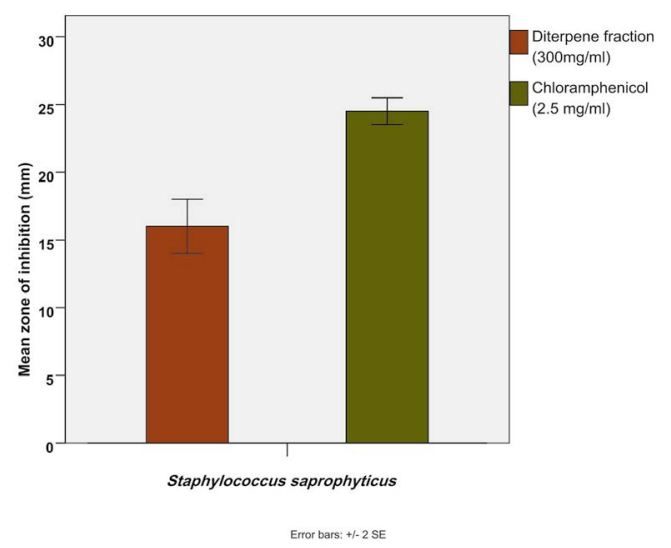

Fig. 1. Susceptibility of Staphylococcus saprophyticus to the extract of Platycladus orientalis compared with chloramphenicol

Table 3. Antibacterial activity of ethyl acetate fraction of fruit of Platycladus orientalis against Staphylococcus saprophyticus

\begin{tabular}{lc}
\hline $\begin{array}{l}\text { Tested } \\
\text { compound }\end{array}$ & $\begin{array}{c}\text { Mean zone of } \\
\text { inhibition }(\mathrm{mm})\end{array}$ \\
\hline
\end{tabular}

\begin{tabular}{ll}
\hline TO $(300 \mathrm{mg} / \mathrm{ml})$ & $16.0 \pm 1.0$ \\
$\mathrm{CH}(2.5 \mathrm{mg} / \mathrm{ml})$ & $24.5 \pm 0.5$ \\
\hline
\end{tabular}

Legend: $\mathrm{TO}=$ Platycladus orientalis (ethyl acetate fraction), $\mathrm{CH}=$ chloramphenicol, mean of two replicates, diameter of the paper disc $=6 \mathrm{~mm}$.
Kauran-16-ol (1.4\%), Isosteviol methyl ester (1.2\%), Podocarpa-8,11,13-triene (0.62\%), Methyl abietate $(0.45 \%)$, Cupressene $(0.23 \%)$ and KetoDihydro-gendunin (0.23\%), (Table 1$)$. Similar study on the fruit oil of Platycladus orientalis (Syn. Thuja orientalis) was conducted in Nigeria, the GCMS revealed the presence of 2-carene (21.1\%), 3-carene (15.8\%), $\beta$-myrcene (8.0\%), terpinen4-ol (7.8\%), cedrol (7.8\%). D-limonene (5.5\%), $\beta$-caryophyllene (5.2\%), $\gamma$-terpinene $(4.7 \%)$ and $\beta$-humulene $(4.2 \%)^{13}$. Variations in the chemical constituents of the same plant species could be attributed to variations in the environmental conditions between different geographical locations.

The antibiotic profile of the investigated strain of Staphylococcus saprophyticus showed that it was resistant to 7 among 16 tested antibiotics, in an average of resistance equals $47.75 \%$ (Table 2 ).

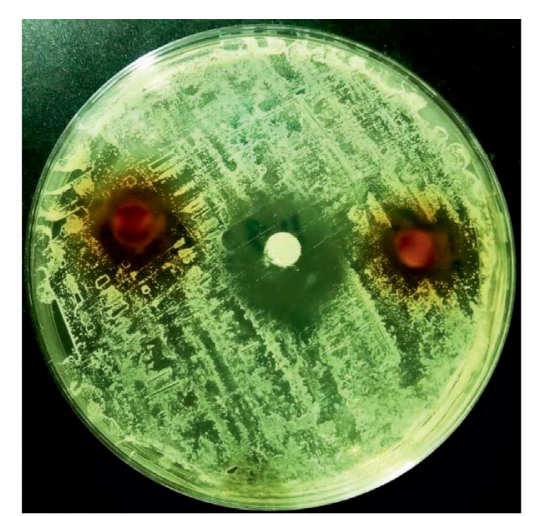

Fig. 2. Representative photo showing susceptibility of Staphylococcus saprophyticus to the extract and antibiotic using disc diffusion test

Table 4. MIC and MBC value of fruits of Platycladus

\begin{tabular}{|c|c|c|c|c|c|c|}
\hline \multirow[t]{2}{*}{ Test } & \multicolumn{6}{|c|}{$\begin{array}{l}\text { Concentration of ethyl acetate fraction } \\
\text { of Platycladus orientalis }(\mathrm{mg} / \mathrm{ml})\end{array}$} \\
\hline & 200 & 100 & 50 & 25 & 12.5 & 6.25 \\
\hline MIC & - & - & - & - & + & + \\
\hline $\mathrm{MBC}$ & - & - & + & + & + & + \\
\hline
\end{tabular}
orientalis against Staphylococcus saprophyticus

$-=$ No microbial growth,$+=$ Presence of microbial growth . 


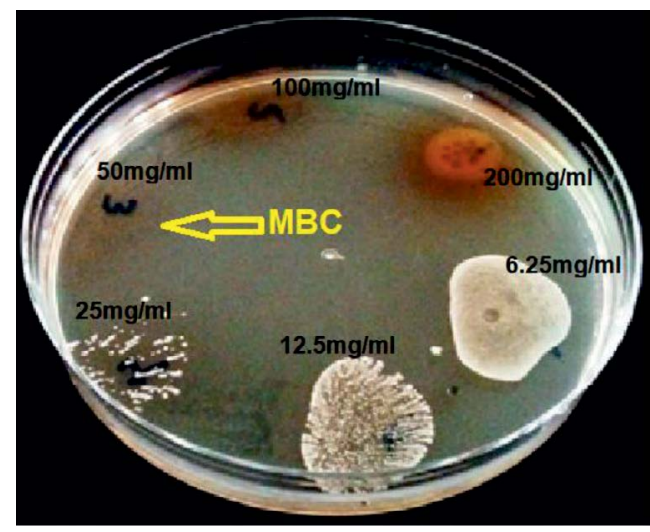

Fig. 3. Representative photo showing determination of $\mathrm{MBC}$ value (white spots are the bacterial growth)

This reflects the urgent need for developing new antibacterial drugs. Staphylococcus saprophyticus is a second most common cause of urinary tract infections, particularly in young women and it is showing growing resistance to antibiotics and requires urgent intervention to curb this serious health phenomenon ${ }^{14}$.

Result of the antibacterial activity of the ethyl acetate fraction of fruit of Platycladus orientalis against Staphylococcus saprophyticus is represented in (Table 3). Which showed that this plant extract has remarkable antibacterial activity, with mean zone of inhibition $16.0 \pm 1.0$, in comparison with the standard drug (chloramphenicol) that recorded $24.5 \pm 0.5 \mathrm{~mm}$ zone of inhibition (Fig. 1 and 2). The RPI, MIC and MBC values supported the findings of the disc diffusion test, which are tabulated in (Table 4), The Relative percentage inhibition (RPI) was calculated and it was found to be $66.6 \%$, which means that the ethyl acetate fraction of fruit of Platycladus orientalis has comparable anti-bacterial efficacy against Staphylococcus saprophyticus. The MIC value was $12.5 \mathrm{mg} / \mathrm{ml}$, whereas the $\mathrm{MBC}$ value was $50 \mathrm{mg} /$ $\mathrm{ml}$ (Fig. 3). Moreover, the MBC/MIC ration is 4, which means that the extract has a bacteriostatic effect on Staphylococcus saprophyticus. It is known that, the plant extract is considered to be bactericidal when the ratio of $\mathrm{MBC} / \mathrm{MIC} \leq 4$, while it is considered bacteriostatic when $\mathrm{MBC} / \mathrm{MIC}$ $\geq 4^{15}$. It was reported that, the essential oil from seed coats of Platycladus orientalis (Syn. Thuja orientalis) has shown good to moderate activity against all six tested bacteria, including Salmonella typhi which was the most susceptible bacteria ${ }^{16}$. Also, the essential oil extracted from fresh fruits of Thuja orientalis (Syn. Platycladus orientalis) recorded remarkable antibacterial effect against all the Gram-positive and Gram negative bacteria tested with MIC values ranging between 12.8 to $25.6 \mathrm{mg} / \mathrm{ml}^{17}$. A recent study stated that, Platycladus orientalis possessed a potential antibacterial activity against hospital-and communityacquired methicillin-resistant Staphylococcus aureus (MRSA) and it was recommended for the control of this pathogen ${ }^{18}$. However, no dataor study was conducted on the antibacterial effect of Platycladus orientalis on Staphylococcus saprophyticus, in particular, and as the best of the authors knowledge this is the first study on this issue. Accordingly, the current study recommends this plant as a potential antibacterial drug against Staphylococcus saprophyticus.

\section{CONCLUSION}

Based on the findings of the current investigation, Fruits of Platycladus orientalis could be used in the formulation of effective antibacterial drug to be used against UTI infections, in particular. However, compounds revealed by the GC-MS analysis should be isolated and studied individually and more future toxicological and pharmacological studies are recommended. Moreover, it is worthy for the pharmaceutical companies to pay great attention to the natural products and medicinal herbs, in order to innovate new effective antibacterial drugs.

\section{ACKNOWLEDGEMENTS}

None.

\section{CONFLICT OF INTEREST}

The authors declares that there is no conflict of interest.

\section{AUTHORS' CONTRIBUTION}

All authors have made substantial, direct and intellectual contribution to the work and approved it for publication. 


\section{FUNDING}

None.

\section{DATA AVAILABILITY}

All datasets generated or analyzed during this study are included in the manuscript.

\section{ETHICS STATEMENT}

This article does not contain any studies with human participants or animals performed by any of the authors.

\section{REFERENCES}

1. Balunas M.J., Kinghorn A.D. Drug discovery from medicinal plants. Life Sci., 2005; 78(5): 431-441.

2. Durand G.A., Raoult D., Dubourg G. Antibiotic discovery: History, methods and perspectives, Int. J. Antimicro. Agents, 2018; doi: https://doi. org/10.1016/j.ijantimicag.2018.11.010

3. Ruos J.L., Recio M.C. Medicinal plants and antimicrobial activity. J. Ethnopharma., 2005; 100: 80-84.

4. Srivastava P., Kumar P., Singh D.K., Singh V.K. Biological Properties of ThujaOrientalis Linn. Advan. Life Sci., 2012; 2(2): 17-20.

5. Chizzola R., Hochsteiner W., Hajek S. GC analysis of essential oils in the rumen fluid after incubation of Thujaorientalis twigs in the Rusitec system. Res. Vet. Sci., 2004; 76(1): 77-82.

6. Breeta R.E., Jesubatham P.D., Grace V.M.B., Viswanathan S., Srividya S. Non-toxic and nonteratogenic extract of Thujaorientalis L. inhibited angiogenesis in zebra fish and suppressed the growth of human lung cancer cell line. Biomed. Pharmaco., 2018; 106: 699-706.

7. Pailhorius H., Cassisa V., Chenouard R., Kempf M., Eveillard M, Lemari' C. Staphylococcus sapro-phyticus: Which beta-lactam?. Int. J. Infect. Dis., 2017; 65: 63-66.

8. Oteo J., Campos J., Baquero F. Antibiotic resistance in 1962 invasive isolates of Escherichia coli in 27 Spanish hospitals participating in the European Antimicrobial Resistance Surveillance System. J.
Antimicro.Chemothera., 2002; 50(6): 945-952.

9. Su P.W., Yang C.H., Yang J.F., Su P.Y., Chuang L.Y. Antibacterial Activities and Antibacterial Mechanism of Polygonum cuspidatum Extracts against Nosocomial Drug-Resistant Pathogens. Molec., 2015; 20: 1111911130.

10. Akinyemi K.O., Oluwa O.K.,Omomigbehin E.O. Antimicrobial activity of crude extract of three medicinal plants used in South-West Nigeria folk medicine on some food borne bacterial pathogens. Afrin. J. Trad. Compl. Alter. Med., 2006; 3(4): 13-22.

11. Doughari J.H. Antimicrobial Activity of Tamarindus indica Linn. Trop. J. Pharmaceut. Res., 2006; 5(2): 597-603.

12. Abdallah E.M. Antibacterial activity of Hibiscus sabdariffa $\mathrm{L}$. calyces against hospital isolates of multidrug resistant Acinetobacter baumannii. J. Acu. Dis., 2016; 5(6): 512-516.

13. Usman L.A., Agboola T.A., Abdul Waheed J.O., Ismaeel R.O., Ogundele V.A., Ibrahim A. Phytochemical profile of fruit and leaf essential oils of Thujaorientalis grown in North Central Nigeria. Nigerian J. Pure Appl. Sci., 2016; 29 (2): 2968-2976.

14. Latham R.H., Running K., Stamm W.E. Urinary Tract Infections in Young Adult Women Caused by Staphylococcus saprophyticus. J. American Med. Asso., 1983; 250(22):3063-3066.

15. Djeussi D.E., Noumedem J.A., Seukep J.A., Fankam A.G., Voukeng I.K., Tankeo S.B., et al. Antibacterial activities of selected edible plants extracts against multidrugresistant Gram-negative bacteria. BMC Compl. Altern. Med., 2013; 13: 164.

16. Jain R.K. and Garg S.C. Antimicrobial activity of the essential oil of Thujaorientalis L. Anc. Sci. Life, 1997; 16(3): 186-189.

17. Shah W.A., Qadir M. Chemical composition, Antioxidant and Antibacterial activity of Thuja-orientalis essential oil. World J. Pharma. Sci., 2014; 2(1): 56-61.

18. Chakraborty S., Afaq N., Singh N., Majumdar S. Antimicrobial activity of Cannabis sativa, Thujaorientalis and Psidium guajava leaf extracts against methicillin-resistant Staphylococcus aureus. J. Integr. Med., 2018; 16: 350-357. 